DOI: $10.2478 /$ pof-2018-0008

VOLUME 10, ISSUE 1, 2018

ISSN: 2036-5438

\title{
Reconstructing Social Dialogue
}

by

\author{
Mariana Pinto Ramos*
}

Perspectives on Federalism, Vol. 10, issue 1, 2018 


\section{Abstract}

The European Social Dialogue, and its output, the European collective agreements, are intended to implement minimum standards of working conditions that bind all MemberStates, in a logic of legal harmonisation of the European Union's social objectives.

However, despite some federal traits of the European Union ("EU"), since the beginning European social dialogue has faced numerous challenges, particularly when confronted with the need to balance economic interests, giving social policies a subsidiary role, and when facing the different agendas of each Member-State.

This article proceeds with a historical analysis of the development of European Social Dialogue, its implementation stages, and past and current challenges, which can be divided in three phases: past experience, present experience and current challenges and, finally, an attempt to project what new social policies might hold for the future.

\section{Key-words}

European Social Dialogue, European collective agreements, European social partners, legal harmonisation, minimum standards of working conditions, federalism 


\section{Introduction}

Throughout the European Union's life, federalism has been a powerful ideology. The goal for the implementation of a gradual "United Nations of Europe" is an old wish but still an embryonic reality, especially as far as the European Social Dialogue is concerned.

Like any federation, the European Union ("EU") was born as a consequence of a voluntary, citizen-based, social contract that was originally aimed as a long-term peacemaking compromise between European countries.

The EU has obvious federal traits, and yet there is no consensus that the EU is, in fact, a federal union, or even has the vocation to become one.

The financial crisis, still affecting EU Member-States, has promoted a more decentralised and non-supportive EU which enhanced the existing, critical, gap between European social policies. Therefore, even though a European federation has always been the final aim of the European construction ever since the Schuman Declaration, the reality is that it is safe to say that the integration process has fallen short of a full political federation.

However, as Andrew Duff, the former President of the Union of European Federalists (UEF) recently said: «the "F-word" is back in town». The flaws of the European monetary union, made apparent by the financial and economic crisis, and the need to revamp economic and social policymaking and the required democratic backing in the EU, have at least allowed federalism to be debated again (Borrell 2014).

The effects of the worst financial and social crisis in decades are being deeply felt and Member States are undergoing rapid and profound changes, especially in the social field: from demographic ageing to new family configurations, from the speed of digitalisation to new forms of work and the impacts of globalisation.

Despite that, the truth is that the EU has always had a social dimension, closely linked to its economic ambitions and it was in this context that the European Social Dialogue was born as the crucial instrument, means (Perez 1999: 15) or method (Veneziani 1998: 248) to promote both competitiveness and fairness in Europe. It is said that countries with a long 
tradition of Social Dialogue tend to have stronger, more stable economies and are often Europe`s most competitive. Hence, acknowledging the importance of the European Social Dialogue as an essential element of the European Social Model (or "Social Europe") and European Governance is a real challenge that EU is facing, especially when economic interests collide with social ones.

The truth is that founding a "Social Europe" is not an easy task since it has, as stated by Commission, different meanings and importance to different parts of society:

i. For some people, the term "Social Europe" is empty words and the EU is perceived as the catalyst of global market forces, the vehicle of commercial interests and the threat of "social dumping" by an unrestrained and unchecked Single Market;

ii. Others contest the very need for a social dimension in the EU, regarding social issues as exclusive matters for their national and regional governments (therefore, EU social policies are perceived as a means to lock out competition);

iii. And for others still, "Social Europe" is core to the EU's contribution to democratic, cohesive, culturally diverse and prosperous societies. It means economic and social progress, fighting against discrimination and social exclusion, making Europeans fit for the labour market and allowing them to live fulfilling lives.

As said, there are various and divergent opinions among Europeans that, in practice, cause impediments to full integration, and the acknowledgement of the social dimension of the EU and its Member-State's needs.

Moreover, the idea of a federal EU is still not well accepted among Member-States, even though there are obvious traits of federalism that have been integral to European history over the years. Indeed, as is typical in many federal states, the EU has a citizens' chamber (the European Parliament) and a states' chamber (the EU council). However, in order to properly speak about federalism, the EU still lacks some fundamental elements: the democratic legitimacy of all its institutions, something that reflects the existence of primary sovereignty, an effective capability in uniform fiscal and social policies, and the ability to act effectively in the international sphere. At the moment, sovereignty still resides 
largely within the States, especially where social policies are concerned (that are still considered as only soft law and, therefore, not legally enforceable).

Notwithstanding its limitations and challenges, the EU is an international innovation, combining intergovernmental/confederal and supranational/federal elements. At best, we can say that the EU is "a federation-in-progress" (Borrell 2014).

Nevertheless, as the Europe of $28^{\mathrm{I}}$ looks to the future, the desire already exists to discuss and further improve the social dimension of the EU, and it is important to take a longer-term perspective regarding social policies so that in times of financial crisis, European Member states are better equipped to provide for their citizens.

\section{The past experience}

The first building blocks of the EU were laid by the then French Minister for Foreign Affairs, Robert Schuman, with his Declaration of 9 May 1950, in which he presented a draft, jointly prepared with Jean Monnet, for the unification of the European coal and steel industries in a European Coal and Steel Community. As a result, the first Treaty at European level - the Treaty establishing the European Coal and Steel Community - was created in 1951 with the aims of not only ensuring European peace, but also boosting economic growth and full employment in a Europe destroyed by War. The Treaty was the beginning of the European Union, but also the first sign of a break with the monopoly of national legislation, with efforts being made towards European unification at all levels (legislative, economic and social).

Following this, the Treaties of Rome - which created the European Economic Community (EEC) and the European Atomic Energy Community (Euratom) - enshrined the original economic vocation of EU law as it focused on economic commitments and the idea of free movement. It was in this context that the first references, albeit weak and fragile, to European social policies emerged, with the reference to "a rapid rise in the standard of living". Despite that, the social provisions scattered throughout the body of the Treaty all arose as a consequence or condition of the economic policies of the free movement of workers.

The Treaties of Rome had given social policy a marginal role, that was seen as a reflection of a process of economic integration rather than as an objective to be pursued as 
such. However, after the Hague Summit of 1969 and, above all, following Werner`s plan for the creation of an economic and monetary union, the focus shifted. The Community's institutions, and European governments, faced with a rising rate of unemployment and a serious economic crisis, began to outline the contours of a social policy attentive to the problems of employment, not only as a reflection of the process of economic integration but also as an autonomous objective, implementing numerous initiatives in the area of employment and vocational training.

On 17 March 1971, the Commission published a Social Policy Program entitled "Preliminary guidelines for a Community social policy program", which set out main objectives of European social policy: the improvement of employment policies, greater social justice and improving the living conditions of workers. The European Commission did not intend to carry out an exhaustive analysis of the social problems of Europe at the time, but rather to set goals and objectives in priority areas. As such it was only a contribution to the analysis of European social policies and development coordination, and the harmonisation of the social legislation of the Member States and the EU (Roberts and Springer 2001).

In this context three directives are adopted:

- Council Directive 75/129 / EEC of 17 February 1975 on the approximation of the laws of the Member States relating to collective redundancies;

- Council Directive 77/187 / EEC of 14 February 1977 on the approximation of the laws of the Member States relating to the safeguarding of employees' rights in the event of transfers of undertakings;

- Council Directive 80/987 / EEC of 20 October 1980 on the approximation of the laws of the Member States relating to the protection of employees in the event of the insolvency of their employer.

At the same time, Social Dialogue at the European level officially began in 1985. The first meetings took place in the Palace of Val Duchesse, Belgium, with the aim of directing the social partners represented by the European Trade Union Confederation (ETUC), the Union of Industrial and Employers' Confederations of Europe (UNICE/ BUSINESSEUROPE) and the European Confederation of Public Enterprises (CEEP) towards participation in the internal market process as negotiators (Lyon-Caen 1997a). 
Following the speech of Jacques Delors in the European Parliament on 12 March 1985, a new social policy initiative, to be implemented by the Single European Act (SEA), was made explicit. As a stimulus to the economic dynamism of Europe, the President of the Commission proposed the promotion of a new cooperation strategy for economic growth and employment and the encouragement of Social Dialogue. It was with the SEA, in its added article 118b, that the EEC Treaty for the first time referred to the opportunity for social partners to establish "conventional relations" at the European level as a means of deepening existing Social Dialogue mechanisms.

Reforms to the extension of the scope of the qualified majority principle strengthened the powers of the Commission, and the role of social partners at the European level, emphasising the need for greater social and economic cohesion of the then twelve Member States.

The SEA had set a key objective for European integration: the completion of the European internal market by the end of 1992. In addition, there had been very significant changes in the social sphere, such as a change in the rules for the adoption of qualifiedmajority directives, and the introduction of the principle of Social Dialogue and conventional relations between the social partners at European level.

Consequently, the EEC Treaty set itself the objective of harmonisation per se; harmonisation which did not depend on any other factors to justify its necessity, to be achieved through a new cooperation procedure with the European Parliament (VogelPolsky 1989: 177-189).

This level of harmonisation entailed the adoption "by means of a Directive of the minimum requirements progressively applicable taking into account the conditions and technical regulations in each Member State", i.e., minimum harmonisation levels. These were minimum, but not minimalist requirements, since the logic of the common minimum requirements aimed to reconcile the ideal of harmonising national legislation with the reality of the diversity of national situations, and as a pre-emptive measure for future enlargements.

This was a new phase of European integration, based on consensus and cooperation between the Member States, but not on releasing them from their social responsibilities. ${ }^{\text {II }}$

Before the SEA, the legal basis of European collective agreement was contested. On the one hand, it was argued that without the conferral of a Community mission to the social partners, the principle of territoriality made European collective bargaining 
unfeasible; on the other hand, the freedom of association and the subsequent rights of organisation and collective bargaining were recognised by the international legal order (which provided for the functioning of the European collective agreement) (Lyon-Caen 1997b: 355). It is in this context that the basis for negotiation for setting working conditions appears alongside legislative sources (regulation, directive, etc.). In addition, the amendment to the qualifying majority measure resulted in the adoption, after 1987, of 15 directives, which shows a significant increase over previous years.

Another important milestone in the evolution of European Social Dialogue and European social policies was the adoption in 1989 of the Community Charter of the Fundamental Social Rights of Workers. ${ }^{\text {III }}$ The adoption of this Charter, by eleven of the twelve Member States, ${ }^{\mathrm{IV}}$ marked a decisive step in the construction of social Europe since it is the first solemn text that recognised and guaranteed a minimum core of fundamental rights to European workers as an affirmation of the European social model and European Social Dialogue. But the Charter also stated that building the single European market must go hand in hand with the creation of a European social space, to eliminate inequalities and avoid social dumping between states (Lamothe 1993: 198).

Subsequently, the creation of what we now know as the EU with the Maastricht Treaty, was a new milestone in the process of European political union. Signed on 7 February 1992, it constituted a turning point in terms of fundamental rights, across various sections, referring to the European Convention on Human Rights and to the European Charter to emphasise the social aspect of European integration.

It was also with this Treaty that an annex - the Social Policy Agreement (SPA), ${ }^{\mathrm{V}}$ resulted in a broadening of possibilities for collective bargaining at the European level. In substance, under this Agreement, the Maastricht Treaty laid the foundations for European Community legislation as well as European collective bargaining (Lamothe 1993: 199).

The SPA recognised Social Dialogue as the basis for European collective bargaining, by adding rules to the Commission on the submission of proposals and consultations with the social partners, as well as the launch of European action. The SPA also envisaged the transposition of directives into the domestic law of the Member States by means of a collective agreement.

The SPA also stipulated that dialogue at European level between social partners could lead to contractual relations, including agreements. The EU would support and harmonise 
Member States' action in various fields: working conditions, the protection of workers' health and safety, the promotion and protection of gender equality between workers, etc.

It also gave priority to contractual arrangements for legislation and promoted consultation with social partners at the European level, using all measures deemed necessary to facilitate their dialogue.

Finally, it opened the door to European collective bargaining, particularly at the sectoral level, and the chance to apply collective agreements in the different Member States, as well as the normative element of collective labour agreements ${ }^{\mathrm{VI}}$ (Coimbra 1994: 72; Coimbra 1999: 150; Lo Faro 2012: 153-156).

Furthermore, the application of these European collective agreements was envisaged, according to the SPA, in two alternative ways:

a) The European agreements shall apply in accordance with the procedures and rules specific to the European social partners and the Member States, and according to the statement of the eleven Member States annexed to the Agreement, will depend on the collective bargaining procedure and the rules of each State. This modality did not require Member States to apply the agreements directly, or establish rules for the transposition of such agreements, or amend existing internal rules to facilitate their application - it is called the autonomous implementation;

b) if such agreements involved matters covered by art. 2 of the Agreement they will be implemented by a Council Decision, on a proposal from the Commission, based on the joint requirements of the European social partners known as the institutional implementation.

Thus, if the Commission projected certain measures, it had first to consult the European social partners - as originally envisaged in Art. 138 (1) and (2) of the Maastricht Treaty and now enshrined in the Treaty of Lisbon in Arts. 154 and 155. The social partners could inform the Commission of their intention to initiate an autonomous negotiation process and the agreements resulting from this process could have had a similar effectiveness to that of Community acts, rather than directives (Biagi:1999).

Following these social measures, one question was raised as to whether the directives that came out would have the value of Community law, which was later confirmed by the Commission. 
Finally, EU competence in the social field was required, following the principle of subsidiarity (Langlois 1993: 201-209). Questions were also raised as to the democratic legitimacy of the social partners' normative action, especially where the problem of representativeness was concerned. In this context, the European Social Dialogue had also emerged as a possible remedy for the democratic deficit through the representativeness of social partners (Gonzálvez 2006: 156-158; Gonzálvez 2011: 110).

Despite the progress made in the Treaty, notably in European social policy, this was not sufficient to meet the urgent need to reform European policy. It was not possible, in fact, to enshrine the objective of a federalist union in the Maastricht Treaty; but it is inevitable that in the long run the EU can develop a strongly federal structure with a principle of subsidiarity (Wessels et. al.: 17-18).

Unlike the SEA and the Maastricht Treaty, the Treaty of Amsterdam was not the result of a political will to give new impetus to European integration. On the contrary, the Treaty represented the culmination of an intergovernmental conference essentially carried out by legislative determination, as it was provided for by the Maastricht Treaty.

The great novelty of the Treaty of Amsterdam regarding social policies was the introduction of the 'principle of flexibility', that is to say, the principle that the Union can move forward in tackling certain areas without having to involve, necessarily, the participation of all Member States. Another new feature of the Amsterdam Treaty on flexibility was the introduction of a general clause in the body of the Treaty establishing the principle of enhanced cooperation between Member States (Ehlermann 1997: 74; Soares 1999: 31).

The Amsterdam Treaty also introduced a new title on employment in the body of its text, where the concept of a coordinated employment strategy, or open method of coordination (internationally known as the Open Method of Coordination - OMC) was significantly developed.

This concept of a coordinated employment strategy set out the method for drawing up employment policies in the form of soft law, i.e., it is the method of drawing up nonbinding policies on employment, which do not necessarily change national policies, but which must be considered by the Member State when the latter are drawn up or amended. This resulted in an acceptable alternative to the reluctant delegation of powers to the European institutions by the Member States, where they agree on general guidelines to be 
applied, under the supervision of the European institutions, in particular the Commission (Regent 2003: 191). This means that choices about social policies remain the national right of each Member State, and European legislation is explicitly excluded (Adnett 2001: 353$364)$.

At the same time, however, national choices were defined on the basis of common concerns and objectives in order to reconcile the efforts of the various Member States and achieve optimal overall results. However, the benefits of this method depended, crucially, on the positive commitment of Member States to the promotion of coordinated solutions. As Scharpf explains, if this were the case, then European recommendations could be used as a powerful argument in national policy discourses. Otherwise, national action plans would simply reflect the status quo of national policies (Scharpf 2002: 654).

This method, used in employment policies, became an exemplar. ${ }^{\mathrm{VII}}$ However, the open method of coordination was not restricted to employment policies because it covered areas such as social protection, business policies and immigration. Moreover, although the European Social Dialogue was not institutionally incorporated through this method, it was in practice substantiated as the social partners were consulted in procedures for the formulation of social employment policies.

In fact, a European Social Dialogue can produce guidelines, based on the open method of coordination, which will become framework agreements which, in turn, can be adopted by Member States in sectoral or cross-sectoral Social Dialogue. This "union of forces" was aimed at improving success in the promotion of social policies. However, the success of the open method of coordination differed across the various areas it covered. In the case of employment policy, it is widely recognised that the open method of coordination was successful, especially as it did not benefit from the inherent advantages of the binding nature of hard law. In other cases, the open method of coordination is relegated to a second option, in favour of legal regulation, which demonstrates that the lack of normative and binding power of this method can be both its strength and its greatest weakness (Rogowski 2008: 22).

European concern for economic growth constrains and undermines the objectives of the open method of coordination, since even when Member States comply with the guidelines established by this method, they are constrained by economic integration, which limits their autonomy in the choice of policies to follow. If, for example, national 
unemployment increases, the objectives set out by the European Economic Area cannot force State aid, and cannot require measures to combat unemployment, since this method is not legally binding. Therefore, Member States are ultimately restricted by the economic objectives outlined in the Treaty, which cannot be ruled out by recommendations or other soft law instruments. The secret of success or failure of the open method of coordination might be its ability to respond, given its range of options that remain available to each Member State, even in the face of limitations imposed by the international economy (Scharpf 2002: 655-666).

Subsequently, the Treaty of Nice entered into force on 1 February 2003 and made possible the institutional reforms necessary for the enlargement of the EU to include Eastern and Southern European candidate countries, by adopting measures such as limiting the size and composition of the European Commission, the extension of qualified majority voting, re-weighting of votes in the European Council and the relaxation of the enhanced cooperation arrangements.

One year after the Treaty of Nice, the European Council, meeting in Laeken, adopted on 15 December 2001 a "Declaration on the Future of the European Union", also known as the "Laeken Declaration", in which the EU made a commitment to become more democratic, more transparent and more effective.

Four key themes were addressed in this declaration: (i) delimitation and definition of competences, (ii) simplification of the Treaties, (iii) institutional architecture (iv) and the way to adopt a Constitution for European citizens. It was from this Treaty that the debate on a possible European Constitution began, a project eventually carried out, with its signature in October 2004.

However, with the reluctance of the Member States to approve a European Constitution and its difficulty of ratification, this project was eventually abandoned. Therefore, the European leaders decided not to move in the direction of a new attempt at a Constitution, but towards a new reforming Treaty for the EU. It was in this context that the Treaty of Lisbon was signed on 13 December 2007 and entered into force on 1 December 2009, establishing the current Treaty on EU (TEU) and the Treaty on the Functioning of the EU (TFEU).

The TEU is undoubtedly the result of further reflection on the part of the EU after the failure of the Constitutional Treaty, and is therefore inspired by its initial objectives, albeit 
with some adaptations. Consequently, the TEU introduced, among other things, a new model of division of powers between the Union and the Member States, established a single legal personality of the EU and merged the three pillars of the Union, dissolving the structure that originated in the Maastricht Treaty. As such, the TEU stated that "The Union shall be replaced and succeeded by the European Community", i.e. the EU would incorporate the European Community, strengthening the Community method. The TEU also made it clear that the EU's powers originate from the Member States, although in the delimitation of competences, there were exclusive competences of the EU and competences shared between the EU and the Member States (as in the case of social policies) (Vitorino 2012: 17-31).

In terms of social policy, the EU Treaty gave greater prominence to certain social rights as axiological foundations of the EU itself, such as respect for human rights, gender equality and non-discrimination in general, combating social exclusion, and social justice and protection.

The TEU, countering the historic trend towards the enhancement of the economic component of the Union, reinforced the concern for social policies by creating a social clause, explicitly recognising the importance of Social Dialogue. This gave more autonomy to social partners, which quickly bore fruit with the translation of new framework agreements into directives, and also the recognition of the binding legal nature of the Charter of Fundamental Rights, giving it a hierarchy of rules equivalent to that of the Treaties themselves. The Treaty thus ensures that these fundamental rights have binding legal force and that they must be guaranteed and respected by national legal systems, and national and European courts (Ramalho 2012: 57-65). ${ }^{\text {VIIIX }}$

Social policies are matters of shared competence between the EU and Member States, i.e. both the Union and Member States can adopt binding legal acts in these areas. In this way, a greater potential for EU intervention in social matters is legitimised.

In this context, another major change of the TEU in terms of social policy was the procedural amendment that allowed the approval of social matters by a qualified majority. The extension of the qualified majority to the social subject of workers made it possible to overcome the obstacles previously created by the rule of unanimity, in particular the difficulties created by the diversity of national systems and their traditions in social matters 
which prevented the reaching of a consensus to approve certain social policies at European level (Boto 2011: 77-80).

Furthermore, the TEU has broadened the scope of the concept of mainstreaming. This concept was previously adopted regarding the principle of gender equality, with the primary objective of (re) organisation, improvement, development and evaluation of policy processes, so that the gender equality perspective would be incorporated into all policies, at all levels and at all stages, by actors normally involved in policy-making.

The TEU is particularly concerned with employment issues, noting that the social objectives of the EU are to promote high levels of employment, to ensure adequate social protection, to combat social exclusion, and improve education, training and health.

The promotion of employment, the improvement of living and working conditions, and the strengthening of the Social Dialogue were also foreseen in the Community strategy for 2020, which provides for the implementation of measures which will lead to the fullest use of the potential of Social Dialogue. Matters such as equality, the fight against labour discrimination, and "flexicurity" $\mathrm{x}$ will form part of the themes to be defined and implemented jointly with the social partners. The Commission intends to carry out a costbenefit assessment of the existing directives to ascertain whether they meet the objectives set, by continuing to promote Social Dialogue with social partners in search of solutions more in line with European needs.

The TEU has brought an original approach to the EU's social problems, alerting the Member States to these issues and reinforcing the guarantees of European workers and citizens in general.

Thus, it can be said that "social dialogue is a driving force of economic and social reforms". The normative coverage for Social Dialogue currently given by the TFEU is very broad. Sectoral and inter-trade dialogue between social partners, and Social Dialogue, are clearly and respectively defined in the Treaty, affording the social partners the formal possibility of building a supranational collective bargaining area and intervening in the detailed content of EU decisions.

Therefore, developing and fostering Social Dialogue is considered an essential element of the European Social Model, since it also complements and supports national social dialogue and industrial relations. In addition, as mentioned by Brian Bercusson "The concept of social dialogue incorporates a principle critical in the EC context. It stipulates a relationship between 
collective bargaining and law which assumes a multiplicity of forms within Member-States and is extremely flexible in its application within the context of Community social policy. Social Dialogue does not simply equate with collective bargaining. It implies a flexible relationship between social dialogue at all levels and Community and national institutions" (Bercusson 1996: 73). Therefore, embracing the fundamental role of the European Social Dialogue as a significant component of EU employment and social policymaking contributes to the formulation of arrangements and instruments that balance the needs of enterprises and workers across Europe.

Nowadays, Social partners have the specific role of shaping legislation in the social field, enshrined in the EU treaty`s social policy chapter. The social partners know the reality of Europe`s workplaces, understand the needs of workers and companies, and defend their interests. Therefore, involving them at the EU level helps ensure that the concerns of both business and workers are considered in initiatives taken at the EU level.

The Commission`s role, on the other hand, is one of support and promotion of the European Social Dialogue. Hence, the Commission consults the social partners prior to any legislative initiative even though social partners can also negotiate agreements on their own, to be implemented in accordance with article 155 TFEU.

Until now, the European Social Dialogue procedure has produced four agreements at cross-industry level, signed by the European social partners, that have then been transformed into directives:

a) The framework agreement of December 1995 on parental leave gave all employees an individual, non-transferable right to at least three months' parental leave until their child reaches a given age (to be defined at national level) and up to eight years.

b) In June 2009, the social partners signed a revised version of their 1995 parental leave agreement and altered the minimum mandatory parental leave period from three months to four months per employee, with at least one month being nontransferable between parents.

c) The framework agreement of June 1997 on part-time work established the principle that part-time workers must not be treated less favourably than comparable full-time workers solely because they work part-time.

d) The framework agreement of March 1999 on fixed-term work laid down the principle that fixed-term workers must not be treated less favourably than 
comparable workers on open-ended contracts solely because they have a fixedterm contract.

There have been four autonomous agreements signed by the European social partners at the cross-industry level:

a) On telework in 2002;

b) On stress at work in 2004;

c) On harassment and violence at work in 2007 ;

d) And inclusive labour markets in 2010 .

Also, autonomous agreements have been concluded at the sectoral and multi-sectoral levels:

a) On the European license for train drivers carrying out a cross-border interoperability service, in 2004;

b) On workers' health protection through the good handling and use of crystalline silica and products containing it, in 2006.

In these cases, the social partners established a general framework at the EU level obliging their national affiliated organisations to implement the agreements in accordance with the national procedures and practices specific of each Member-State. That said, these agreements were not legally binding, and hence not enforceable on the Member-States.

European Social Dialogue has also resulted in process-oriented texts, such as frameworks of action, guidelines, codes of conduct, joint opinions, among other tools.

However, outcomes of Social Dialogue can go beyond soft law, in the form of framework agreements transposed by Council decision or binding autonomous agreements. For example, in 2013, the EU cross-industry social partners signed a framework of action on youth employment where they committed to promoting solutions to reduce youth unemployment and called national social partners, public authorities and other stakeholders to also actively work towards that goal (Gonzálvez 2011: 92).

\section{The present challenges}

Despite all the efforts involved in promoting the European Social Dialogue, some obstacles remain to their formal consolidation in the European area and in national legal systems. Obstacles such as tensions between the European and the national, over the 
harmonisation of social rules and respect for specific social practices, over betting on short-term competitiveness or long-term quality of development.

In this way, the Social Dialogue is faced with obstacles to its consolidation which have been difficult to overcome. The lack of organisation of social partners is one such obstacle; here the low level of trade unionism, and the reluctance of employers to join European employers' organisations, pose the crucial problem of the representativeness of European social partners in the EU. In addition, there is the problem of the concentration of collective bargaining at the company level and the problem of the diversity of legal systems and the plurality of national social models, which make it impossible to carry out a common and concerted Social Dialogue.

Nevertheless, Social Dialogue is undoubtedly a fundamental instrument for change, because it combines an increase of competitiveness with solidarity. At the national level, as well as at the European level, the information, negotiation and Social Dialogue dimensions need to be developed. Strengthening the European Social Dialogue, in its various forms, could lead to solutions that improve the functioning of enterprises by combining adaptability with security. It should be noted, however, that policy on wage-fixing, tradeunion rights, the lock-out and the right to strike remain exclusively national powers, with minor future openings regarding cross-border strikes. However, these material limitations to the EU's competence should be understood as confined to the core of the institutions in question and not to all its collateral aspects, according to the principle accesorium sequitur principale (Sciarra 1993: 323; Blanpain 2002: 122; Boto 2011: 81).

Faced with these obstacles, many raise the question of whether there is in fact a genuine European Social Model, which promotes a genuine European Social Dialogue or whether, on the contrary, this model is a myth. Others accept the existence of a European Model, but question whether this model is truly social and European. Still others accept the existence of a European Social Model, but do not bet on its sustainability, as they believe that the challenges that this model must overcome are too great for its weak structure. The challenges facing the European Social Model are, at first glance, the same as those faced by Member States: globalisation, competition, inequalities, enlargements, economic and social developments, aging of the population, etc. (Weiss 1990: 97-108).

In fact, European policies - and social policies are no exception - are regulated within the diverse cultures, languages, semantics, ideologies and policies of the various Member 
States that are part of the EU. For this reason, the European Social Model and European Social Dialogue are seen in contrasting ways within the EU. For some, they are a source of inspiration and hope for a more united, cohesive and supportive Europe, but for others it is an open door for the loss of national sovereignty, political constraints and unreachable social objectives (Branch 2005).

However, despite the dissenting voices, it seems that in recent decades the European Social Model, and the European Social Dialogue, have been established in the minds of European citizens and are already part of the national political concerns and agendas of the Member States.

The European Social Model could be an aspiration to achieve, but it is not real. It is a vision of society that combines sustainable economic growth with a continuous improvement of living and working conditions. This implies efforts to achieve full employment, good quality jobs, equal opportunities, social protection for all, social inclusion and citizen involvement in the decisions that affect them. For these reasons, social dialogue, collective bargaining and worker protection are key elements in promoting European productivity and competitiveness. This is what distinguishes European and Anglo-Saxon social systems, namely the North-American system, where only a few benefit at the expense of the majority. However, what is meant by sustainable economic growth, full employment or good quality jobs, remains to be defined. These are concepts which, in themselves, vary according to the socio-political view of each Member State and which are easily transmuted according to the economic-social vicissitudes of global Europe.

The current situation of the global economic crisis that has drastically affected Europe, especially the southern countries such as Portugal, has pushed the European Social Model into the background, with preference given to economic growth, often accompanied by measures which undermine the efforts made to promote social policies, in terms of improving working conditions, full employment, better salaries and investment in human capital.

This means that the European Social Model and the European Social Dialogue are still fragile concepts that, despite all the efforts made for their autonomy, continue to be dependent on strong financial performance and the collaboration of Member States. So, what has happened so far is that if the economy declines, and measures are needed to 
combat the crisis, social policies are the first to succumb to the economic demands that always prevail.

Hence, while we may speak of the improvement of working conditions at a time when unemployment rates are at their highest, and wage and social dumping are being promoted, it remains clear how economic interests can destroy, in a short space of time, all the social ideals that actors have tried to build through the implementation of the European Social Model over the last decades.

Some authors believe that the fragility of the European Social Dialogue and the European Social Model is primarily due to the lack of representative power of the European social partners (Bercusson 1996). In fact, as already mentioned, there are certain matters, notably pay negotiation and strike action, which are beyond the reach of the European social partners, and are reserved for national legislation where national social partners can intervene. In other words, if there is no real Social Dialogue between the EU and Member States, more specifically between the European and national social partners, the European Social Model and the European Social Dialogue can very easily be - or continue to be - sacrificed to the requirements of national economic policies.

Notwithstanding all these obstacles, the European Social Model exists, is a reality and its work has borne positive fruit. Despite the diversity in the European social area, and within the respect of shared competences between the EU and Member States, the European Social Model has consolidated itself as a coherent set of policies, structures and objectives that substantiate its existence. The aim of a "social market economy" is to show the European synergy that has been created over the years between the need to merge economic objectives with social obligations within the European area, to create a satisfactory balance for all.

Analysing the principal outputs from the European Social Dialogue, and the implementation of social policies, the majority is related to labour matters, related to the promotion of employment, equality in work, improvement of working conditions, among others. It is already common ground among Member States that social employment policies are the way forward, not only to avoid social exclusion and social dumping, but also to promote long-term social growth, to ensure adequate funding pensions, social security, health and the improvement of living conditions in general (Gonzálvez 2011: 132135). 
However, the European Social Model faces the problem of a lack of institutional effectiveness. Values and principles alone do not make a difference; there is a need for appropriate legislative support, which is only binding on European institutions. In this context, there has been an attempt to promote the harmonisation of labour legislation in the EU, albeit without much success. Firstly, Member States do not welcome the EU's intention to override national sovereignty when it comes to legislating on social issues.

In addition, the diversity of cultures and social objectives in the various Member States of the EU makes it impossible to implement a single institutional model regarding social policies. Thus, the open method of coordination, which took its first steps in the last decades, has been the method that the Member States have most graciously accepted. This is because policy coordination does not mean harmonisation or unification of policies (Regent 2003: 190-194).

While a policy of harmonisation has been able to achieve the minimum standards, that of coordination is intended to go further. This method leaves effective social policy decisions in the hands of Member States, but attempts to improve these decisions by promoting common goals to be adopted alongside common indicators achieved through the benchmarking of national performances. This promotion of common objectives may be made essentially using soft law instruments, but they are nonetheless European instruments for the implementation of social policies. This means that, even if they lack binding force, these instruments are still instruments that keep Member States on the right track for the implementation of social measures that everyone thinks are necessary. However, there is nothing to prevent Member States from following a different path, since they are not bound by the social policies imposed by the EU, excepting binding framework agreements, implemented in national laws through the transposition of EU directives. Apart from this alternative, the European Social Model depends on the willingness of Member States to collaborate with European institutions and with European social partners, and on the existence of a European social conscience that is stronger than the temptation to regulate states' own interests to the detriment of the European collective interest (Gonzálvez 2011: 129-132).

That said, European Social Dialogue still needs further development, especially in times of economic crisis, where social problems intensify, inequalities increase, social exclusion intensifies, and economic and social interests overlap. The European Social Dialogue is an 
essential mechanism of the European Social Model, but both are weakened by the lack of institutional autonomy. The greatest challenge of the European Social Dialogue remains its role in the future of European policy and the recognition of the autonomy of social partners. The European Social Dialogue is weakened in its procedure and results. In other words, social partners need to strengthen their autonomy, and, in particular, the respect given to them by the European Commission and other European institutions. European Social Dialogue must go beyond social dialogue at the national level, since it should cover all national social dialogue and not just replicate it, at the risk of losing its useful meaning.

In sum, the European Social Model and the European Social Dialogue are still fragile realities, without proper institutional autonomy (Smismans 2008: 170-178). In fact, the strength of the European Social Dialogue depends to a substantial extent on the efforts of national social dialogue, and the role that national social partners play in their own national arenas. In this way, if the national dialogue falls short of what is expected, it will inevitably endanger the European Social Dialogue.

However, the winds apparently started to change when, in September 2015, President Jean-Claude Juncker (re)stated the Commission intentions for the labour market, as following:

"We have to step up the work for a fair and truly pan-European labour market. As part of these efforts, I will want to develop a European Pillar of Social Rights, which takes account of the changing realities of Europe's societies and the world of work. And which can serve as a compass for the renewed convergence within the euro area. This European Pillar of Social Rights should complement what we have already jointly achieved when it comes to the protection of workers in the EU. I believe we do well to start with this initiative within the euro area, while allowing other EU Member States to join in if they want to do so."

The discussion on the social dimension of Europe is part of a broader debate initiated on the future of EU28. ${ }^{\mathrm{XI}}$ The recent reflection paper on the social dimension of Europe, published alongside the European Pillar of Social Rights, focuses on the profound transformations that European societies and the world of work will undergo in the coming decade, outlining the importance of the renewal of the concept of a Social Europe.

Despite the different impacts the financial and economic crisis has had in various parts of Europe, across the Union, it is the younger generations that have been hit particularly hard - for example, at the end of 2016, youth unemployment rate stood at $18 \%$ in the EU 
and $20 \%$ in the euro area. That means that, for the first time since the World War II, there is a real risk that today`s young adults - the most educated generation ever in the history of EU - may end up less well-off than their parents, and that would mean that the European project has failed miserably.

In this context, and to invert the damaging process that has been created in the past decade due to the economic crisis, the European Commission recently issued its recommendation on the principles and rights that are essential for a fair, well-functioning labour market and welfare system to address the needs of today`s Europe.

The Commission Recommendation for the establishment of a European Pillar of Social Rights, applicable to all Member-States (firstly for the euro area but extensive to all EU Member States) consists of 20 key principles that serve merely as a high-level guide for better working and living conditions in Europe. However, it is presented with both current and future realities in mind.

Even though Europe has shown signs of financial growth, with constantly reducing overall unemployment rates, the effects of the last decade's crisis are still visible in youth unemployment rates and the risk of poverty in many parts of Europe. At the same time, European countries are facing rapid changes taking place in the labour market. Therefore, according to the optimistic and forward looking approach of the European Commission, there are as many challenges as are opportunities of growth.

In this context, the European Pillar of Social Rights is all about delivering new and more effective rights for citizens, even though it is not expected to apply a "one-size-fits-all" approach, since the Pillar acknowledges the diversity of social realities amongst European countries (Cavallazzi et al. 2017).

In brief, the principles under the Social Pillar fall into three categories:

- equal opportunities and access to the labour market;

- fair working conditions;

- and social protection and inclusion.

These principles, as the European Commission has already stated, need further legislative or non-legislative initiatives to become effective. However, the main point is that the European Commission is sending a clear message to all Member-States on what is expected of them in the social field. 
As specific measures, the European Commission has adopted a new proposal on worklife balance, and launched two social partners consultations: (i) on modernising the rules of labour contracts; (ii) on access to social protection.

In the work-life balance proposals, the European Commission envisages extended paternity, parental and carer`s leave, as well as protection against discrimination or dismissal if workers ask for leave or flexible working arrangements.

The social partners consultations will also look at labour contracts, and at how to provide social protection to all workers, including the self-employed or those with "nonstandard" work contracts.

Nevertheless, the Pillar is not a rigid document, it gives room for improvement, and social innovations are encouraged from all actors. Also, given the legal character of the Pillar, these principles and rights are not directly enforceable, because they require a translation into dedicated action and/or separate legislation, at the appropriate level.

However, the European Commission not only wants to improve social and labour legislation, but also (and primarily) enhance and raise awareness of existing legislation, promoting its fully implementation and enforcement. In this key aspect, the social partners play a key role, since they are in a privileged position to influence national policies so that these comply, in a harmonising matter, with key resolutions of the European Commission regarding social aspects of EU.

\section{What the future holds?}

EU leaders, in the Rome Declaration of $25^{\text {th }}$ March of 2017, stated that

"In these times of change, and aware of the concerns of our citizens, we commit to the Rome Agenda, and pledge to work towards (...) a social Europe: a Union which, based on sustainable growth, promotes economic and social progress as well as cohesion and convergence, while upholding the integrity of the internal market; a Union taking into account the diversity of national systems and the key role of social partners; a Union which promotes equality between women and men as well as rights and equal opportunities for all; a Union which fights unemployment, discrimination, social exclusion and poverty; a Union where young people receive the best education and training and can study and find jobs across the continent; a Union which preserves our cultural heritage and promotes cultural diversity." 
Considering the financial and economic crisis that has swamped the EU since 2008, the current, major aim of the EU is to mitigate the already existent social disparities between Member-States. Linked to this is the aim of promoting convergence towards higher living standards, since this has slowed considerably - if not come to a halt - on the last decade.

Therefore, it is important to create a more cohesive and more stable EU, especially where living and working conditions are concerned. It is also urgent to reconstruct and relaunch Social Dialogue, at national and European levels.

The renewal of a social Europe is not just a social necessity, but also an economic imperative. Employment and social conditions vary widely across the euro area, as result of the crisis, and its consequences impact on the credibility and sustainability of a strong and unified EU.

As pointed in the European Commission`s report, efficient and resilient labour markets promote high levels of employment, and can absorb shocks without generating unemployment which are essential for the smooth functioning of the Economic and Monetary Union. Overtime this will contribute to the convergence of performances between Member-States and promote more inclusive societies.

Since the creation of the Pillar of Social Rights, the main job of the European Commission will be to, at the European level, mobilise the various instruments available: EU law - with an emphasis on the enforcement of the existing rich acquis, to be updated and complemented where necessary; Social Dialogue, to engage with and support the work of EU social partners; policy guidance and recommendation; and financial support.

However, elements of resistance are still visible from some European countries that consider that the European Commission promotes a federalist discourse, but that goal could be counterproductive, since it can promote and encourage the exit of other countries from the EU, as the UK recently did.

Nevertheless, looking beyond Europe, a federation might be the only way Europeans have to face challenges that states alone would never be able to overcome, in the global context. Considering the new emerging economies, with millions of inhabitants, such as China, India and Brazil, Europe must remain a relevant international actor in a global context and for that to happen it must become a united international actor. 


\section{Conclusions}

The truth is that EU is not a federal union (yet). For some, a Federation - as the institutional representation of federalism as an ideology (King 1982: 20.) - is not only desirable but necessary to establish a more democratic and effective Europe that is needed to play a key role in a globalised world. On the other hand, there are several countries that are not willing to give more powers to the EU or change the decision-making rules.

The renewal of concerns from the EU regarding social policies indicates a new phase for European Social Dialogue, a willingness to reconstruct what was once abandoned for economic interests.

However, this desire is compromised by the mixed feelings the Member States have towards EU intervention in social policies.

Consequently, reconstructing the role of social partners and the European Social Dialogue itself is urgent and necessary, to obtain the best working conditions and employment policies that the Member States are willing and able to implement, in a harmonised way.

It is our understanding that federalism should be increasingly discussed in the EU and not treated as a taboo subject regardless of the existence or lack of federal elements. Nevertheless, we must not forget that, more and more, globalisation is reshaping the political, economic and social destinies of the world, with new international actors and, as such, the nations of Europe can only safeguard their prosperity and their social achievements by joining forces and standing together on several key issues. This requires, sooner or later, new steps towards a federal union (Borrel 2015).

Our goal with this paper was to establish a connection with the UPP and with a soaring reality that is the EU, as a sui generis federation. Through a solid analysis of the UPP and its integrating components, it is possible to understand the advantages that a reshaped system can bring to the single market and the promotion of scientific and technological developments in the EU. As was demonstrated, it must be reiterated that patents with unitary effect will not be the only unitary title in Industrial Property Law, as it will add to a harmonised system of both EU trademarks and designs, strengthening it, that shows the relevance of this step forward. Nevertheless, it cannot go unnoticed that there are still 
some obstacles that prevent this system from reaching its true potential. The coexistence with an international agreement, like the EPC, the different judicial reviewers and the nonparticipation of all the EU Member-States in the framework of the UPP represent some of these obstacles.

Despite these challenges, the post-UPP European Patent System will be more coherent, uniform and adapted to the single market, which is an economy with even more worldwide impact. As such, the overwhelming majority of EU Member-States are interested in this cooperation, only if complemented with the respect for their sovereign interests (as it is in the present case). In conclusion, and defending an approach which concentrates the subject-matter of a federation in a clear search for unity, we sustain that the UPP is an EU federal manifestation.

\footnotetext{
* Master in Labour Law by the Faculty of Law of the University of Lisbon, Lawyer specialised in Labour Law, Member participant of the Young Scholars Section of ISLSSL, Member of the Portuguese Association of Labour Law (APODIT) and of the Association for Young Portuguese Labour Lawyers (AJJ). This paper is the revised and full version of the author's presentation at the "More Eu Conference: The federal experience of the European Union: past, present and future" that took place at Nova Law School in Lisbon, on the $22^{\text {nd }}$ and $23^{\text {rd }}$ of May 2017.

I Or, being more precise, the EU27 after the conclusion of "Brexit".

II It should be borne in mind, however, that before this stage social policies were the sole responsibility of the Member States, and that this amendment promoted an extension of the powers of the Community institutions and increased cooperation between Member States.

III Notwithstanding the political and social value that its approval had, the Charter is not binding.

IV The United Kingdom abstained.

${ }^{v}$ Not endorsed by the United Kingdom, which had always taken the position that social issues fall under the exclusive competence of national rights

VI However, the obligation of transposition lies with the Member States, and is normally fulfilled through appropriate legislative and administrative activity. Any Member State can rely on the social partners, at their joint request, to conclude agreements aimed at "ensuring the results" imposed by the respective directives.

VII At the aforementioned Luxembourg Summit in November 1997, better known as the "Luxembourg Process", where the method of coordination was exhaustively specified and developed and anticipated, it was stated that the objective of this strategy was to reduce unemployment, significantly, in Europe within five years. The strategy established a multilateral surveillance framework comprising inter alia a joint annual report on employment, employment guidelines on which the national action plans developed by the Member States.

VIII These principles already resulted from the TEU (Nice version), in its arts. $1^{\circ}-\mathrm{A}$ and $2^{\circ}$, but it is with this TUE that they gain a more comprehensive dimension.

Ix Although most of these principles already result, in general, from articles (1a) and (2) of the Treaty of Nice, the norm is now more comprehensive, with references to non-discrimination in general and minorities as a novelty.

X Flexicurity is considered "an integrated strategy for enhancing, at the same time, flexibility and security in the labour market. It attempts to reconcile employers' need for a flexible workforce with workers' need for security - confidence that they will not face long periods of unemployment'. See Communication from the Commission to the European Parliament, the Council, the European Economic and Social Committee and the Committee of the Regions - Towards Common Principles of Flexicurity: More and better jobs through flexibility and security (COM/2007/0359 final).
} 


\section{References}

- $\quad$ Adnett Nick, 2001, 'Modernizing the European Social Model: Developing the Guidelines', Journal of Common Market Studies, XXXIX(2): 353-364.

- Aguilar Gonzálvez Maria Cristina, 2006, "La negociación colectiva en el sistema normativo", Lex Nova, Valladolid.

- Aguilar Gonzálvez Maria Cristina, 2011, 'El diálogo social, ¿una herramienta para el futuro?’, Revista del Ministerio de Trabajo e Inmigración, Derecho social Internacional y Comunitario, 107-139.

- $\quad$ Aubin Claire, 2007, 'L'Europe sociale entre mythe et réalité', Droit Social, no. 5: 618-622.

- $\quad$ Bercusson Brian, 1996, European Labour Law, Butterworths, London.

- Biagi Marco, 1999, 'The role of social partners in Europe: from dialogue to partnership', Comparative Labor Law \& Policy Journal, XX(3): 485-796.

- $\quad$ Blanpain Roger, 2010, European Labour Law, 12 $2^{\text {th }}$ edition, Kluwer Law International, Alphen aan de Rijn.

- Blas López Maria Esther, 2006, 'Le cadre d`action des partenaires sociaux européens: panorama, mutations et enjeux à l'heure de la mondialisation', Droit Social, no. 5: 540-561.

- $\quad$ Borrel Josep, 2014, 'Is a Federal Europe Possible?', The Federalist Debate, XXVII(3), available at: http://www.federalist-debate.org/index.php/current-issue/comments/item/924-is-a-federal-europepossible.

- Branch Anne, 2005, 'The evolution of the European Social Dialogue towards greater autonomy challenges and potential benefits', International Journal of Comparative Labour Law and Industrial Relations.

- Brouillet Jacques et al., 2006, 'Le modèle social européen: source ou moteur de la construction européenne?', Droit Social, no. 12: 1176-1182.

- $\quad$ Cavallazzi Ron Galea, Vella Marisa and Mizzi Edward, 2017, The European Pillar of Social Rights and its implications on employment, available at www.lexology.com.

- Chassard Yves, 2007, 'Un modèle social européen par défaut', in Dehove M. (ed), Le nouvel état de lEurope, La Découverte, Paris

- Correia António, 2010, 'O diálogo social europeu', Revista Tribunal Reg. Trabalho, $3^{a}$ Reg., Belo Horizonte, LI, no. 81: 185-194.

- Decker Franck, 2002, 'Governance beyond the nation-state. Reflections on the democratic deficit of the European Union', Journal of European Public Policy, IX(2): 256-272.

- Ehlermann C.D., 1997, 'Différenciation, flexibilité, coopération renforcée: les nouvelles dispositions du traité d'Amsterdam', Revue du Marché Unique Européen, no. 3: 51-90.

- $\quad$ Erhel Christine and Palier Bruno, 2005, 'L`Europe sociale: entre modèles nationaux et coordination européenne', Revue d'économie politique, no. 6: 677-704.

- $\quad$ Franssen E., 2002, Legal aspects of the European Social Dialogue, Intersentia, Antwerp - Oxford - New York.

- Keiser Wolfram and Varsori Antonio, 2010, European Union History: Themes and Debates, Palgrave Macmillan, Basingstoke.

- $\quad$ King Preston, 1982, Federalism and Federation, Johns Hopkins University Press, Baltimore.

- Lo Faro Antonio, 2012, 'Bargaining in the shadow of optional framework? The rise of transnational collective agreements and EU law', European Journal of Industrial Relations, XVIII: 153-165.

- Lynch-Fannon Irene, 2006, 'The European Social Model of Corporate Governance: Prospects for Success in an Enlarged Europe', in Ali P. and Gregoriou G.N. (eds), International Corporate Governance After Sarbanes-Oxley, Wiley, Hoboken NJ, 423-443.

- Lyon-Caen Antoine, 1997a, 'Le rôle des partenaires sociaux dans la mise en œuvre du droit communautaire', Droit Social, no. 1: 66-74.

- Lyon-Caen Antoine, 1997b, 'La négociation collective dans ses dimensions internationales', Droit Social, no. 4: 352-367.

- Miranda Boto José María, 2011, 'Las competencias de la Unión Europea en materia social: panorama y perspectivas de futuro', Revista del Ministerio de Trabajo e Inmigración, Derecho social Internacional y Comunitario, 75-105. 
- Monereo Perez Jose Luis, 1999, Concertación y diálogo social, Lex Nova, Valladolid.

- $\quad$ Petit Benoît, 2010, 'Un regard juridique sur la dynamique du modèle social européen', Droit Social, no. 2: 213-222.

- Ramalho Maria do Rosário, 2012, 'O Tratado de Lisboa e o Modelo Social da União Europeia. Algumas Notas', in O Tratado de Lisboa, Almedina, Coimbra, 57-70.

- Regent Sabrina, 2003, 'The Open Method of Coordination: A New Supranational Form of Governance', European Law Journal, IX(2): 190-214.

- $\quad$ Roberts Ivor and Springer Beverly R., 2001, Social policy in the European Union: between harmonization and national autonomy, Lynne Riener, Boulder.

- Rogowski Ralf, 2008, 'The European Social Model and Transitional Labour Markets', in Law and Police, Studies in Modern Law and Police, Ashgate, 9-27.

- Schäfer Armin and Leiber Simone, 2009, 'The double voluntarism in EU social dialogue and employment Policy', in Kröger Sandra (ed), What we have learnt: Advances, pitfalls and remaining questions in OMC research, European Integration online Papers (EIoP), Special Issue 1, Vol. 13, Art. 9, available at: http://eiop.or.at/eiop/texte/2009-009a.htm.

- Scharpf Fritz W., 2002, 'The European Social Model: Coping with the Challenges of Diversity', Journal of Common Market Studies, XL(4): 645-670.

- Sciarra Silvana, 1993, 'European Social Policy and Labour Law - Challenges and Perspectives', CCAEL, IV(1): 301-340.

- Sisson Keith, 1999, "The "new" European Social Model: the end of the search for an orthodoxy or another false dawn?', Employee Relations, XXI(5): 445-462.

- Smismans Stijn, 2008, 'The European Social Dialogue in the Shadow of Hierarchy', Journal of Public Policy, XXVIII(1): 161-180.

- Smismans Stijn, 2007, 'The European Social Dialogue between constitutional and labour law', European Law Review, XXXII: 341-364.

- Soares António Goucha, 1999, 'DE ROMA A AMESTERDÃO: O caminho da integração europeia', SOCIUS - Centro de Investigação em Sociologia Económica e das Organizações, no. 1/99: 1-35.

- Veneziani Bruno, 1998, 'Dal dialogo sociale alla conttratazione collettiva nella fase della trasformazione istituzionale dell'Unione Europea', Rivista Giuridica del Lavoro e della Previdenza Sociale, XLIX(2): 239-286.

- Vitorino António, 2012, 'As Inovações do Tratado de Lisboa', in O Tratado de Lisboa - Jornadas organizadas pelo Instituto de Ciências Jurídico-Políticas da Faculdade de Direito da Universidade de Lisboa, Almedina, Coimbra.

- Vogel-Polsky Éliane, 1989, 'L`Acte unique ouvre-t-il l`espace social européen?', Droit Social, no. 2: 177-189.

- Weiss Manfred, 1990, 'Perspectives of the European Labour Law and Industrial Relations', in Biagi Marco (ed), Towards a European Model of Industrial Relations?, Kluwer Law International, Alphen aan de Rijn, 97108.

- Welz Christian, 2008, The European Social Dialogue Under Articles 138 and 139 of the EC Treaty - Actors, Processes, Outcomes, Wolters Kluwer Law \& Business, Kluwer Law International, Alphen aan de Rijn.

- Wessels Wolfgang et al., 'A Europa de A a Z - Guia da integração Europeia', in Institut für Europäische Politik, European Commission, n.d., available at: https://www.ucc.ie/archive/hdsp/Ato \%20Z/pdf/Az pt.pdf.

- Wickham James, 2002, 'The End of The European Social Model: Before It Began?', in National Forum on Europe, Appendix II.

\section{Official Documents}

- $\quad$ COM (2017) 2025 of 1 March 2017, White Paper on the future of Europe, Reflections and scenarios for the EU27 by 2025.

- Guardiancich, Igor; Molina, Oscar, Talking through the crisis: social dialogue and industrial relations trends in selected EU countries / edited by Igor Guardiancich and Oscar Molina; International Labour Office, Governance and Tripartism Department. - Geneva: ILO, 2017. 
- $\quad$ European Commission, Brussels, 26.4.2017 SWD(2017) 201 final - Establishing a European Pillar of Social Rights \{COM (2017) 250 final $\}$

- European Commission, Brussels, 26.4.2017 COM (2017) 250 final Communication from the Commission - Establishing a European Pillar of Social Rights \{SWD(2017) 200 final\}

- A new start for Social Dialogue, European Commission, Directorate-General for Employment, Social Affairs and Inclusion, August 2016

- European Commission, Employment and Social Developments in Europe Annual Review 2016, December 2016

- Reflection Paper on the Social Dimension of Europe, European Commission COM (2017) 206 of 26 April 2017

- $\quad$ Role of Social Dialogue in European Economic and Social Governance, $n^{\circ} 104-$ Industrial Relations in Europe, June 2016

- $\quad$ Eurofound, Role of the social partners in the European Semester, Christian Weltz, February 2016, available

http://www.eurofound.europa.eu/sites/default/files/ef publication/field ef document/ef1570en.pdf.

- COM/2007/0359 final of 26 of June 2007 - Communication from the Commission to the European Parliament, the Council, the European Economic and Social Committee and the Committee of the Regions Towards Common Principles of Flexicurity: More and better jobs through flexibility and security 